Revista de la red interuniversitaria de estudios sobre las literaturas rioplatenses contemporáneas en Francia

$14 \mid 2016$

Levrero

\title{
Ensamblando a Mario
}

Alexander Torres Astacio

OpenEdition

Journals

Edición electrónica

URL: http://journals.openedition.org/lirico/2333

DOI: $10.4000 /$ lirico.2333

ISSN: 2262-8339

Editor

Réseau interuniversitaire d'étude des littératures contemporaines du Río de la Plata

\section{Referencia electrónica}

Alexander Torres Astacio, «Ensamblando a Mario », Cuadernos LIRICO [En línea], 14 | 2016, Publicado el 07 junio 2016, consultado el 24 septiembre 2020. URL : http://journals.openedition.org/lirico/2333 ; DOI : https://doi.org/10.4000/lirico.2333

Este documento fue generado automáticamente el 24 septiembre 2020

\section{cc) (i) (2)}

Cuadernos LIRICO está distribuido bajo una Licencia Creative Commons Atribución-NoComercialSinDerivar 4.0 Internacional. 


\section{Ensamblando a Mario}

\section{Alexander Torres Astacio}

\section{REFERENCIA}

Montoya Juárez, Jesús. Mario Levrero para armar : Jorge Varlotta y el libertinaje imaginativo. Montevideo : Trilce, 2013.142 p. 
Este libro de Jesús Montoya Juárez constituye un esfuerzo inicial de difundir un estudio introductorio a la obra literaria del uruguayo Jorge Mario Varlotta Levrero (1940-2004), conocido más bien por su semiseudónimo Mario Levrero, conformado por su segundo nombre y segundo apellido. El cometido de familiarizar a un público lector académico con la narrativa singular de Levrero coincide con las reediciones de su obra en este siglo, que hasta hace muy poco ha circulado de forma limitada. Si bien esta concurrencia podría interpretarse como el aprovechamiento de lo que está literariamente en boga, el estudio de Montoya Juárez revelará más bien una representación objetiva y no mitificadora de la evolución biográfico-literaria de este

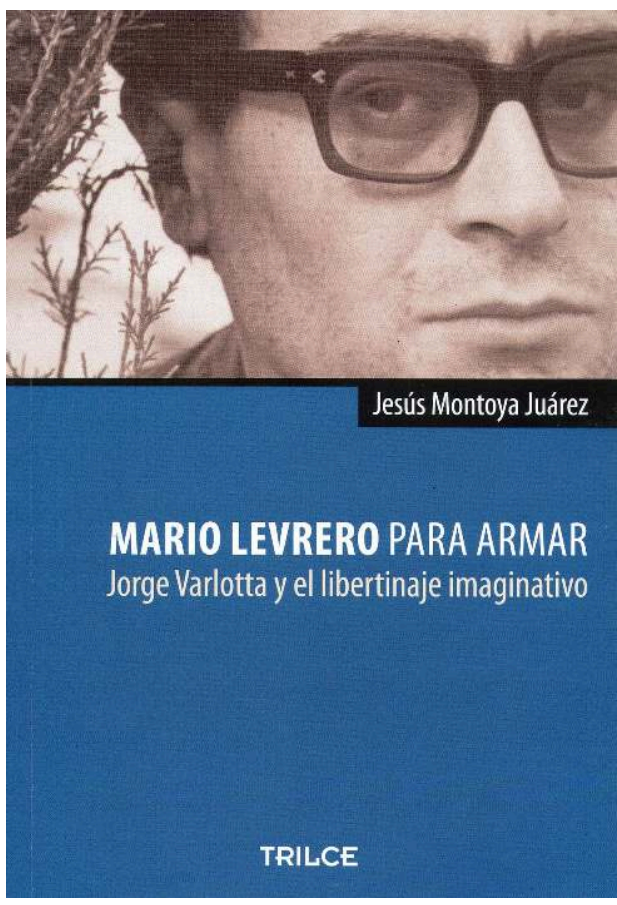
escritor "de culto" y una lectura seria de su obra. El libro del crítico está conformado por ocho capítulos y una breve introducción, pero nos limitaremos a comentar lo que consideramos la información más pertinente.

2 La primera parte del libro trata sobre la vida, la personalidad y el desarrollo artísticointelectual de Mario Levrero. Montoya Juárez resume de forma bastante detallada la vida y personalidad del autor, pero su pretensión no es, como se sugiere más arriba, partir de las excentricidades del autor para hacer una lectura biografista de su narrativa. Superadas ya las limitaciones teórico-empíricas de la "muerte del autor", el crítico no descarta cómo la formación, la vida y la visión particular que Mario Levrero tenía de la escritura literaria pueden ayudar a entender su obra. De hecho, es el punto de partida más lógico tomando en cuenta que se está dando a conocer al escritor uruguayo de forma integral, por así decirlo, y no fragmentaria. Por ejemplo, escribe Montoya Juárez que "[d]e acuerdo con Levrero la literatura formaría parte del conjunto de operaciones preparatorias para la percepción de una plenitud apenas intuida o, digámoslo en sus términos, una "experiencia luminosa". Esa función removedora queda expresada temáticamente en sus relatos en la figura de la búsqueda, elemento común a todas sus ficciones, y quizás el legado primario de la obra levreriana: su particular modo de hacer conexión con la vida" (14). Aunque la crítica no debería limitarse sólo a lo que el autor dice de su labor artística, la continua divagación narrativa y la constante búsqueda de los protagonistas de algo persistentemente escurridizo en los relatos de Levrero -que presentan un mundo vagamente realista intervenido constantemente por imágenes de naturaleza onírica- no sólo caracterizan su estética, sino que también suscitan preguntas de carácter ontológico y epistemológico, preguntas que el autor parece estar haciéndose y lanzando al mundo. Pero al crítico no le interesa ahondar en los "planteamientos metafísicos" (15), esto es, en asuntos relativos a la existencia, sugeridos en la narrativa levreriana. No obstante, Montoya Juárez ofrece a los que quieren acercarse a Levrero no sólo una lectura clara de diferentes aspectos del autor y 
su obra, sino también unas herramientas interpretativas que de forma general son acertadas y útiles.

3 Otra particularidad importante del libro es la manera en que Montoya Juárez reivindica la narrativa de Levrero, desconocida por muchos no sólo por el desinterés del escritor por el éxito editorial, sino por una cantidad limitada de textos académicos dedicados a su obra y porque la crítica de su literatura "se encuentra sobre todo publicad[a] en la prensa rioplatense" (Olivera Olivera 14). Paradójicamente, a partir de la incursión "seria" de Mario Levrero en la escritura, su narrativa fue comentada tempranamente (en la década de 1960) por Ángel Rama con las connotaciones que luego detecta Montoya Juárez. Afirma éste, pues, que "la crítica del autor de Transculturación narrativa en América Latina está a medio camino entre lo estético y lo moral. El elogio de Rama a los primeros textos de Levrero incluye veladamente una reconvención al autor por su "libertinaje" imaginativo, un término con el que valora la originalidad de Levrero, pero con el que también censura su "imaginación excedida"' (Montoya Juárez 73). Como bien reitera el crítico, la reprensión velada de Rama señala el efecto que tuvo sobre la literatura levreriana el "desviarse del cultivo del fantástico cortazariano, donde los vínculos con lo sociopolítico son claros" (121). En otras palabras, en el contexto literario en que emerge la narrativa de Levrero, políticamente interpelado por el capitalismo anglosajón y el comunismo cubano-soviético y luego reprimido por las cruentas dictaduras militares del Cono Sur, para ser legitimada una literatura, ésta tenía que vincularse de alguna forma $u$ otra al compromiso político de izquierda. Y la obra del escritor uruguayo, a pesar de los escarceos con el izquierdismo de su país en la década de 1960, en esencia pasa por alto la temática política. Pero por más que Montoya Juárez defienda el valor de la obra levreriana más allá de cualquier posición política, termina leyendo al autor "en clave política", pues, según él, "podemos interpretar la vindicación de una narrativa como la de Levrero como realista en tanto expresa la crisis de la identidad que cristalizará unos años más tarde en la sinrazón de la violencia militar; además, porque esta crisis identitaria en lo individual proyecta posibles lecturas de alcance político" $(28,110)$. Aunque al hacer esto Montoya Juárez le da involuntariamente la razón a Rama, la que "justifica" que Levrero fuera "injustamente relegado por la crítica" (Verani 803), hace bien de todas formas en no descartar la posibilidad de leer su narrativa en clave política ya que esa búsqueda interminable de sus protagonistas también puede interpretarse como un efecto general de los cambios profundos que se dan en numerosas culturas a nivel global gracias al avance del capitalismo moderno, el cual no puede desarticularse de la cierta ideología política. Ésta última es una lectura que se echa en falta en el libro del crítico.

4 Una de las propuestas más útiles e ingeniosas de Montoya Juárez es utilizar el concepto de la écfrasis para entender la diégesis levreriana. Según el crítico, la écfrasis -la descripción de una obra de arte visual-, que relaciona con el concepto del simulacro -el cual problematiza la distinción entre lo real y lo ficticio-, será la base retórico-teórica a partir de la que se entenderán el proceso y el producto literarios de los relatos de Levrero. Montoya Juárez sostiene que "podríamos concebir [la narrativa levreriana] como una verdadera poética ecfrástica. En este sentido, ha reivindicado el propio autor un papel preponderante de la imagen onírica en el despliegue de su universo narrativo" (82). A nivel formal, la figura y procedimiento retóricos de la écfrasis son perfectamente aplicables a la literatura del escritor uruguayo. 
5 Otra propuesta teórica más arriesgada que la anterior es relacionar ciertos patrones al parecer iterativos en la obra de Levrero con los objetos geométricos que se autorreproducen a diferentes escalas denominados fractales por Benoît Mandelbrot. Pero, como menciona Luis Alfredo Intersimone en una reseña del libro de Montoya Juárez, "por mucho que se menciona el fractal, sólo se ofrece un ejemplo preciso. En [la novela] París, el protagonista se fija en unas baldosas de una estación de trenes y señala que la misma estación aparece dibujada en las baldosas" (396). Además, el mismo Montoya Juárez parece revelar el posible forzamiento de aplicar el conjunto matemático que define el fractal a la obra del autor uruguayo : "Interesa señalar que, si bien Levrero estuvo interesado en las teoría de Mandelbrot años después, no es seguro que las conociera en el momento de la escritura de su novela [París]" (98). Criticando las repetidas referencias al fenómeno natural o conjunto matemático -ambos conocidos como fractales- que Montoya Juárez enfatiza en el desarrollo de su estudio, Intersimone descarta esta relación señalando, por una parte, que el crítico "parece confundir fractalidad con mera fragmentación" y, por otra, aseverando que "a lo largo de la historia de la literatura esta iteración de una estructura dentro de otra ya había sido descubierta y bautizada : se la llamó mise-en-abîme" (396). Pero pensamos que esta propuesta teórica de Montoya Juárez, por más que tenga que refinar el planteamiento y demostrar más ejemplos, es rescatable y sugerente. Por mucho que Levrero haya conocido o no las teorías de Mandelbrot cuando emprendió la novela París, "escrita en 1970 y publicada en 1979" (Montoya Juárez 12), no es imprescindible que estuviera enterado de ellas, puesto que los fractales son un fenómeno que ocurren en la naturaleza. El escritor no tiene que ser consciente de todo lo que contribuye a la creación de una obra literaria de su autoría. Es más, Montoya Juárez, al usar ese ejemplo de París, no se refiere simplemente a la reproducción de una estructura dentro de otra, sino a la "autosemejanza y crecimiento iterativo" de los fractales (129). Según el crítico, "[m]uchos de los personajes levrerianos bucean en la espiral de imágenes interiores que les salen al paso en las ficciones, atravesando capas o niveles que se autorreplican, a menudo alcanzando estados de ánimo y pensamientos que se contienen unos en otros, asociados a esas imágenes" (130). De todas formas, se echa en falta la inclusión de más ejemplos de la supuesta fractalidad que se da en la obra de Levrero. Para concluir esta cuestión, tal vez se podría ayudar a rescatar esta idea definiéndola como una metáfora de los patrones diégeticos presentes en la narrativa levreriana.

6 En resumen, el libro de Jesús Montoya Juárez tiene áreas que podrían ser mejoradas, como desarrollar el tema de la fractalidad en Levrero (si es que es realmente válido) y elaborar una sección sobre cómo se puede leer su obra en el contexto de la modernidad capitalista. De todos modos, demuestra el compromiso e inteligencia de un crítico que quiere difundir la obra de Mario Levrero de forma seria. Maneja de manera equilibrada los datos biográficos del autor y el análisis literario. Este libro abarcador sobre la figura y narrativa del escritor uruguayo, de lectura clara y amena, sin duda resultará ser una obra de referencia indispensable a la hora de acercarse al universo levreriano. 


\section{BIBLIOGRAFÍA}

Obra citadas

Intersimone, Luis Alfredo. Reseña de Mario Levrero para armar. Jorge Varlotta y el libertinaje imaginativo, por Jesús Montoya Juárez. Revista de Estudios Hispánicos 49.2 (2015) : 394-396.

Montoya Juárez, Jesús. Mario Levrero para armar : Jorge Varlotta y el libertinaje imaginativo. Montevideo : Trilce, 2013.

Olivera Olivera, Jorge Ernesto. Intrusismos de lo real en la narrativa de Mario Levrero. Madrid : Universidad Complutense de Madrid, Servicio de publicaciones, 2008.

Verani, Hugo J. “Narrativa uruguaya contemporánea : periodización y cambio literario.” Revista iberoamericana 58.160 (1992) : 777-805.

\section{AUTORES}

\section{ALEXANDER TORRES ASTACIO}

University of Florida 